solids and ash which is of decided value in detecting the addition of ash material in the case of adulterated or imitation vinegars. The curves showing the variations in this ratio for these runs have been plotted in Fig. 3 .

The results of this investigation show conclusively that vinegar manufactured by the generator process is uniform in its composition; as uniform as the ciderfrom which it is prepared-in which respect it differs materially from the vinegars manufactured by the old barrel process. With the exception of the conversion of the alcohol into acetic acid there is but little change in the composition of the cider as it is being converted into vinegar. The most marked difference, other than the oxidation of the alcohol into acid, is the elimination, or, perhaps, destruction of the fixed acids. Here there appears to be an almost constant loss during acetification. On the other hand, there is a considerable formation of pentosans in the generator. No appreciable loss in solids or non-sugars takes place, and the other constituents are practically unaffected. The amount of glycerol in the cider remains almost unchanged by its passage through the generator, and, as it is a product of the alcoholic fermentation, it is an important factor for the detection of adulteration in commercial vinegars. The percentage of ash in the non-sugar solids is remarkably constant, varying only within slight limits, and is of decided value as a standard for judging the purity of cider vinegars.

The results indicate plainly that, given the composition of a hard cider to be used in the manufacture of vinegar by the generator process, it is possible to approximate very closely the composition of the vinegar which can be made from it.

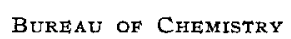

U. S. DEPT. OF AGRICULTURE WASHINGTON

\section{ON THE DECREASE OF AVAILABLE PHOSPHORIC ACID IN MIXED FERTILIZERS CONTAINING ACID PHOS- PHATE AND CALCIUM CYANAMID}

By R. N. BRACEETT

Received July 25, 1913

About two years ago one of the fertilizer companies in this state found that one of their brands ran deficient in available phosphoric acid, although it was thought that ample provision had been made in overage for that ingredient. A representative of the company stated that calcium cyanamid had been used as one of the ingredients of his mixture. As this material usually contains an excess of free lime it appeared possible that the cause of the deficiency in available phosphoric acid in his goods might be traceable to the fact that the soluble or the reverted phosphoric acid had been to some extent converted into insoluble.

Preliminary experiments ${ }^{1}$ on mixtures containing cyanamid showed that there was a slight decrease of available, due to the increase of the insoluble over that calculated for the mixture.

In the early spring of I 9 I 2 a mixer in a near-by town made up a mixture to analyze: ro per cent available

1 Made by L. D. Boone. Results not available. phosphoric acid, 4 of ammonia and 4 of potash, using calcium cyanamid as one ingredient of his mixture. $H$ is formula was as follows:

\begin{tabular}{|c|c|}
\hline \multirow[b]{2}{*}{ Acid $p$} & Pounds \\
\hline & 1250 \\
\hline Calcium cyanamid. & 200 \\
\hline Dried blood......... & 250 \\
\hline Muriate of potash........ & 175 \\
\hline $1 / 2$ and $1 / 2$ mixture (composed of $1 / 216$ per cent acid & \\
\hline phosphate and $1 / 2 \mathrm{C}$. S. meal, damaged $\ldots . . . \cdots$ & 125 \\
\hline
\end{tabular}

Upon having this mixture analyzed in a commercial laboratory it was found to be deficient in available phosphoric acid. We received a sample through a purchaser, and also found it deficient in available phosphoric acid, analyzing about $8-4-4$, instead of Io-4-4. At our request this mixer consented to send us samples of the materials above mentioned.

Before these materials were received, we made up a mixture ${ }^{1}$ of an acid phosphate and cyanamid, using the proportions given above. The acid phosphate used gave as an average of six analyses:

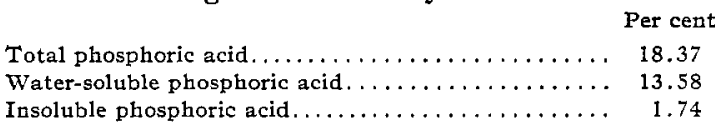

On a 0.3 gram sample, the cyanamid analyzed 4.97 per cent of nitrogen.

The mixture consisted of 250 grams of the acid phosphate and 40 grams of cyanamid, a ratio of one part of the cyanamid to 6.25 parts by weight of the acid phosphate; the initial temperature of the materials was $2 \mathrm{I}^{\circ} \mathrm{C}$. and upon mixing the temperature increased to $32^{\circ} \mathrm{C}$.

\begin{tabular}{|c|c|c|c|c|}
\hline \multicolumn{5}{|c|}{ RESULTS (ZERBST AND HUTSON) } \\
\hline & Total & $\begin{array}{l}\text { Water- } \\
\text { soluble }\end{array}$ & $\begin{array}{l}\text { Insol- } \\
\text { tuble }\end{array}$ & $\begin{array}{l}\text { Availa- } \\
\text { ble }\end{array}$ \\
\hline Original acid phosphate....... & 18.37 & 13.58 & 1.74 & 16.63 \\
\hline $\begin{array}{l}\text { Analysis of the mixture, calcula- } \\
\text { ted, if no change on mixing.... }\end{array}$ & 15.84 & 11.71 & 1.50 & 14.34 \\
\hline $\begin{array}{l}\text { Average of five analyses, } 5 \text { days } \\
\text { after mixing } \ldots \ldots \ldots \ldots \ldots \ldots\end{array}$ & 15.82 & 3.96 & 1.58 & 14.24 \\
\hline $\begin{array}{l}\text { Average of three analyses, } 12 \\
\text { days af ter mixing.......... } \\
\text { Average of four analyses, } 19 \text { days }\end{array}$ & $\cdots$ & 3.54 & 1.69 & 14.13 \\
\hline $\begin{array}{l}\text { after mixing................. } \\
\text { Average of six analyses, } 26 \text { days }\end{array}$ & $\cdots$ & 3.45 & 1.78 & 14.04 \\
\hline $\begin{array}{l}\text { after mixing................ } \\
\text { Average of two analyses, } 33 \text { days }\end{array}$ & . & $\cdots$ & 2.28 & 13.54 \\
\hline $\begin{array}{l}\text { after mixing................ } \\
\text { Average of three analyses, } 40\end{array}$ & $\cdots$ & $\cdots$ & 2.75 & 13.07 \\
\hline $\begin{array}{l}\text { days after mixing............ } \\
\text { Average of three analyses, } 47\end{array}$ & $\cdots$ & $\cdots$ & 3.21 & 12.61 \\
\hline 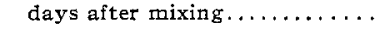 & $\cdots$ & $\cdots$ & 3.57 & 12.25 \\
\hline
\end{tabular}

These results would appear to indicate that the conversion of the water-soluble or of the dicalcium phosphate to tricalcium is not simply a function of the temperature and of the alkalinity of the cyanamid, as is held by some, but that the element of time is perhaps of equal importance with the temperature. Hence it might well happen that a mixture freshly made up would show the required and desired amount of available, and yet be found deficient when analyzed some weeks later. The results of this experiment

1 This work was done by G. H. Zerbst and H. M. Hutson. 
indicate that it would be very interesting to continue the analyses until the water-soluble had ceased to decrease and the insoluble to increase, and it is our hope to be able to take up this problem in the near future, working on a much larger scale.

On receipt of the above mentioned samples, a mixture was made of 3300 grams of the acid phosphate and 528 grams of the cyanamid, being a ratio of one part by weight of the cyanamid to 6.25 parts by weight of the acid phosphate; the materials were mixed in a glass jar; the initial temperature of the materials was $22^{\circ} \mathrm{C}$; ; upon mixing, the temperature rapidly increased to $52^{\circ} \mathrm{C}$. As a mean of three anaiyses, the acid phosphate was found to have the following composition:

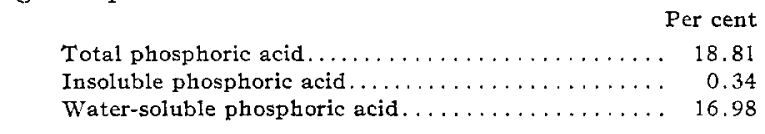

\begin{tabular}{|c|c|c|c|c|}
\hline \multicolumn{5}{|c|}{ RESUITS--(ZERBST AND HUTSON) } \\
\hline & Total & $\begin{array}{l}\text { Water- } \\
\text { Soluble }\end{array}$ & $\begin{array}{l}\text { Insolu- } \\
\text { ble }\end{array}$ & $\begin{array}{c}\text { Availa- } \\
\text { ble }\end{array}$ \\
\hline $\begin{array}{l}\text { Original acid phosphate......... } \\
\text { Analysis of mixture, calculated, }\end{array}$ & 18.81 & 16.98 & 0.34 & 18.47 \\
\hline $\begin{array}{l}\text { if no change on mixing........ } \\
\text { Analysis of samples drawn within } \\
\text { a few days after mixing, mean } \\
\text { of } 8 \text { samples.................. }\end{array}$ & 16.21 & 14.64 & 0.29 & 15.92 \\
\hline $\begin{array}{l}\text { Average of three samples drawn } \\
\text { three weeks later............ }\end{array}$ & $\cdots$ & 1.25 & 2.30 & 13.87 \\
\hline
\end{tabular}

The work had to be discontinued at this point, as no more time was available for the men who had undertaken it. It is noteworthy that, while the watersoluble decreased only from I.9I to I. 25 in three weeks, the insoluble increased from. I. 35 to 2.30 per cent.

Last February, E. L. Hutchins, chemist to a near-by fertilizer plant, reported difficulty in making up a I $0-4-4$ mixture, using as one ingredient of his mixture calcitum cyanamid. I regard this as the best instance of the danger of the decrease of the available phosphoric acid in mixtures in which cyanamid is used, which has come under my observation; and as an especially excellent illustration, as these experiments were conducted on a factory scale. With the permission of Mr. Hutchins, I give the following account of his experiments:

Formula USED

1250 pounds of 16 per cent acid phosphate 100 pounds of 10 per cent Kanona tankage

150 pounds of 11 per cent dried fish scrap

100 pounds of 16 per cent dried blood

150 pounds of 18 per cent eyanamid

52 pounds of 25 per cent sulphate of ammonia

140 pounds of 50 per cent muriate of potash

58 pounds of 18 per cent hard salts

2000

The acid phosphate actually analyzed:

Total phosphoric acid $\ldots \ldots \ldots \ldots \ldots \ldots \ldots \ldots \ldots \ldots, 17.24$

Insoluble phosphoric acid $\ldots \ldots \ldots \ldots \ldots \ldots \ldots \ldots \ldots, \quad 0.89$

Available phosphoric acid................. 16.35

The above formula was made up as follows:

First day's run, Janwary 20,1913, amount made up 180 tons Second day's run, January 21, 1913, amount made up 171 tons Third day's run, January 22, 1913, amount made up 171 tons
Each of these runs was dumped into the same pile, sampled the same day and analyzed the next day. Samples were also taken the 24 th and the 28 th of January, and on the $5_{\text {th }}$ of February, and these sam. ples were analyzed with the following results:

\begin{tabular}{|c|c|c|c|c|c|c|c|}
\hline & & \multirow[b]{2}{*}{$\begin{array}{l}\text { Mois- } \\
\text { ture }\end{array}$} & \multicolumn{3}{|c|}{ Phosphoric acid } & \multirow[b]{2}{*}{$\underset{\substack{\text { nia } \\
\text { Ammo- }}}{ }$} & \multirow[b]{2}{*}{$\begin{array}{l}\text { Pot- } \\
\text { ash }\end{array}$} \\
\hline & & & Total & $\begin{array}{l}\text { Insol- } \\
\text { uble }\end{array}$ & $\begin{array}{l}\text { Avail- } \\
\text { able }\end{array}$ & & \\
\hline 1. & Jan. $21,1913 \ldots$ & 11.22 & 11.67 & 1.68 & 9.99 & 4.12 & 4.76 \\
\hline 2. & Jan. $22,1913 \ldots$ & 11.90 & 11.79 & 1.68 & 10.11 & 4.02 & 4.30 \\
\hline 3. & Jan. $23,1913 \ldots$. & 11.66 & 11.65 & 1.80 & 9.85 & 4.13 & 4.38 \\
\hline 4. & Jan. $24,1913 \ldots$. & 11.02 & 11.72 & 2.35 & 9.37 & 4.13 & 4.09 \\
\hline 5. & Jan. $28,1913 \ldots$ & 10.48 & 11.70 & 2.99 & 8.71 & 4.21 & 4.31 \\
\hline 6. & Feb. $5,1913 \ldots$ & 9.70 & 12.25 & 3.37 & 8.88 & 4,18 & 4.22 \\
\hline
\end{tabular}

The sample analyzed January 28 th was taken from the "face of the pile" and that of February 5th from the "base of the pile." Mr. Hutchins' attention was first attracted by the results of the analysis of January 24 th, and he was led thereby to draw and analyze the other samples. It is evident from these results that in a mixed fertilizer containing acid phosphate and cyanamid in the ratio of one part of the latter to 8.33 of the former, there is an increase of the insoluble and a consequent decrease of the available phosphoric acid on standing, even a week or two; this change may cause the fertilizer to become deficient in available phosphoric acid.

Mr. Hutchins kindly furnished us with a considerable quantity of each of the materials used in his formula. Owing to some misunderstanding, the mixture was made up of one part of cyanamid to 9.8 parts of the acid phosphate. The rise of temperature was only six or eight degrees, but even with this ratio there was a gradual increase of the insoluble, as shown by the following results:

In the formula were used 6667.62 grams of acid phosphate and 680. I grams of cyanamid, with the remainder of the ingredients in proportion.

\begin{tabular}{|c|c|c|c|c|}
\hline \multicolumn{5}{|c|}{ RESUITS-(L. D. HUTSON AND J. F. KING) } \\
\hline & Total & $\begin{array}{l}\text { Water- } \\
\text { soluble }\end{array}$ & $\begin{array}{l}\text { Insolu- } \\
\text { ble }\end{array}$ & $\begin{array}{l}\text { Availa- } \\
\text { ble }\end{array}$ \\
\hline Original acid phosphate........ & 17.50 & 13.09 & 0.68 & 16.82 \\
\hline $\begin{array}{l}\text { Calculated analysis of the mix- } \\
\text { ture, made up March 1st, if no }\end{array}$ & & & & \\
\hline change on mixing $\ldots . . \ldots \ldots \ldots$. & 11.58 & 8.67 & 0.47 & 11.11 \\
\hline Analysis, sample drawn April & & & & \\
\hline $\begin{array}{l}12,1913 \ldots \ldots \ldots \ldots \ldots \ldots \ldots \\
\text { Analysis, sample drawn April }\end{array}$ & $\cdots$ & 8.06 & 0.76 & $\ldots$ \\
\hline $\begin{array}{l}18,1913 \ldots \ldots \ldots \ldots \ldots \ldots \\
\text { Analysis, sample drawn April }\end{array}$ & . & . & 0.81 & $\ldots$ \\
\hline $\begin{array}{l}24,1913 \ldots \ldots \ldots \ldots \ldots \ldots \ldots \\
\text { Analysis, sample drawn May } 2 \text {, }\end{array}$ & $\cdots$ & 7.96 & 1.11 & \\
\hline $1913 \ldots \ldots \ldots \ldots \ldots \ldots$ & $\cdots$ & .7 .94 & 1.14 & $\ldots$ \\
\hline Analysis, sample drawn May 9. & & & & \\
\hline $1913 \ldots \ldots \ldots \ldots \ldots \ldots$ & $\ldots$ & 7.24 & & $\cdots$ \\
\hline
\end{tabular}

In addition to the facts above adduced, it may be interesting to state, as pointing in the same direction, that of the 70 samples of complete fertilizers found deficient in available phosphoric acid alone, during the past fertilizer season, seven were registered as hav. ing calcium cyanamid as one of their ingredients; eleven brands were not registered at all; and it is more than likely that cyanamid was an ingredient of many of the remaining 52 samples though the fact was not stated in the registration. 
Acknowledgments are due Assistant Professor G. F. Lipscomb for his careful oversight of the work of the students; to the students themselves and to Mr. E. L. Hutchins for furnishing us with materials and for the use of his experiments and results.

\section{CONCLUSIONS}

I. From experiments conducted in this laboratory, it has been shown that when cyanamid is mixed with acid phosphate in the ratio of one part of the former to 6.25 or 8.33 or even 9.8 of the latter, there is, on standing, a gradual increase of the insoluble and consequent decrease of the available phosphoric acid in the mixture, and that this is true whether the mixture consists simply of the acid phosphate and cyanamid, or whether ammoniates and potash salts are also present.

II. The experience of at least three manufacturers working on a factory scale has shown that there is a decrease of the available phosphoric acid when calcium cyanamid and acid phosphate are used in mixed fertilizers in the ratio of one part of the former to 6.25 or 8.33 of the latter, thus confirming our own work done on a small scale.
III. The results of our fertilizer inspection analysis this past season point to the same fact; $i$. $e$., that there is danger of falling off in the available phosphoric acid when calcium cyanamid and acid phosphate are used together as ingredients of a mixed fertilizer.

IV. The results of all these experiments indicate that the time element has an important influence in determining the increase of insoluble phosphoric acid, and must be considered in addition to the elements of temperature and the alkalinity of the cyanamid.

$V$. It appears from the facts given in this paper, that, though it may be said that the effect of mixing cyanamid with acid phosphate will not injure the fertilizer from the farmer's standpoint, the manufacturer must exercise some care as to the amount of the cyanamid used in a mixture, else his mixture may, upon inspection and analysis, be found deficient in available phosphoric acid.

Chemical DePartMent

Clemson Agricultural, Cori,Ege South Carolina

\section{LABORATORY AND PLANT}

\section{THE DESIGN OF AN EXPERIMENTAL WOOD DISTILLA-} TION PLANT

Bÿ H. K. Benson aNd Marc Darrin

Received August 18, 1913

The utilization of waste wood in the Pacific Northwest has recently attracted much attention. The interest lies partly in the necessity of clearing the logged off or "cut over" lands which now number over three million acres in the State of Washington alone. In a more popular sense, the interest, however, centers about the waste wood of the sawmills. In the latter it has been the practice to install wood burners or incinerators to dispose of the mill waste, and hundreds of cords of wood are thus destroyed daily. In the popular mind this waste is regarded as an economic crime, and several efforts have been made to establish a wood distillation industry in the Northwest, all of which have been commercial failures.

With a view to giving some assistance in solving this problem the University of Washington coopperated for some time with the Bureau of Plant Industry of the United States Department of Agriculture in land clearing studies and at the present time is in cooperation with the United States Forest Service in certain yield studies of distillation products from both Douglas fir stumps and the waste wood of sawmills operating in the western part of the State of Washington. After some years of experience with this problem, both from a theoretical standpoint and from practical participation in the industry, it appeared to the senior author of this paper that the failure of the commercial plants could, in each case, be traced to inferior and unusual methods of operation rather than to inferior products and lack of market as usually asserted. After personal visitation of the principal distillation plants in the
United States by both of us, we selected the type of plant described in this article as most nearly applicable to economical operation in the distillation of mill waste. The plant thus designed has been erected coopperatively by the United States Forest Service and the University of Washington and is now in operation. In this article only the design of the plant will be described since the results obtained will be the subject of later publications by the Forest Service.

The general layout of the plant is indicated by the legend descriptive of Plate I. The wood for distillation is measured (4), weighed (3), placed in retort buggies (7), and distilled in the retort (2x). The products of distillation are conducted from the retort through a bottom vapor outlet $(25)$, into the tar separator (26), thence into the condenser (29), and finally the gases are stored in the gas holder ( 14 ), where they are sampled and measured and finally pass to the furnace (r8) for combustion. For the estimation of the liquid products, the distillate is pumped (39) from the pyroligneous acid tank (30) into a feed tank (38), from whence it flows by gravity into a copper still (36) heated by steam coils. The resulting distillate is separated (40) into light oil and crude wood vinegar (containing acetic acid, methyl alcohol, acetone, etc.) and stored in tanks for sampling.

The main interest centers, however, in the design of the retort. For experimental purposes a capacity of one-half cord was determined upon, which required dimensions approximately $\mathrm{I} 8$ feet $\mathrm{I}$ inch long. The shell of the retort is 4 feet I inch wide and 3 feet 2 inches high, made of one-fourth inch steel and is covered on the outside to a thickness of two inches with standard heat insulation material. At one end a furnace is provided, the heat from which is conducted 